\section{Evidence that gaseous anesthesia may be due to neuronal hypoxia}

Despite much research the mode of action of gaseous anesthetic agents has proven elusive since the use of ether was first reported by Morton and Parkman in 1847. As anesthetic gas mixtures contain at least $20 \%$ oxygen and the minimum alveolar concentration of an anesthetic agent producing an immobilizing effect does not change over a wide range of inspired oxygen concentrations, it would appear unlikely that hypoxia is involved. However, normal levels of oxygen in blood cannot ensure adequate oxygen tensions within cells and intracellular oxygen concentrations cannot be measured.

The progression and reversibility of neurological deficits due to hypoxia, from leg immobility to unconsciousness, were published in the Lancet in 1862 by James Glaisher ${ }^{1}$ after a balloon ascent to an altitude equivalent to the height of Everest. Aware of these exploits, Claude Bernard in 1875 suggested hypoxia may be involved in anesthesia produced by volatile agents, as did Verworn in 1912 but were unable to produce evidence. At the turn of the century, Meyer $^{2}$ and Overton ${ }^{3}$ observed that gaseous anesthetics have a high lipid to water solubility ratio but, although this has been confirmed, it has been found that molecules that have similarly high lipid solubility are not anesthetics. They are now classified as "non-immobilizers."

The discovery of the protein hypoxia-inducible factor 1 , the subject of the award of the 2019 Nobel Prize for Physiology or Medicine, has provided a unique marker of intracellular hypoxia. Hypoxia-inducible factor 1 has been detected when a sub-anesthetic concentration of xenon and oxygen is breathed to simulate the hypoxia induced at high-altitude. Hypoxia-inducible factor 1 and the effector hormone, erythropoietin, are up-regulated by hypoxia and the effect lasts many hours longer than an exposure induced by breathing a low oxygen partial pressure. ${ }^{4}$

In 1961, Linus Pauling" published "A Molecular Theory of General Anesthesia" observing that gaseous anesthetic agents are, firstly, non-hydrogen bonding and, secondly, they form clathrates - lattices of water molecules in membranes, which trap gas molecules by van der Waals forces. His paper discusses xenon, which is inert under biological conditions, but an excellent anesthetic. Figure 1 shows the diagram of the lattice from his paper representing xenon.

Other inert gases, for example, argon, also produce anesthesia at

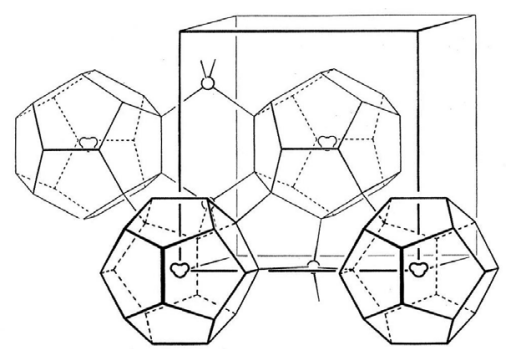

Figure 1: The structure of the $12-\AA$ hydrate crystals of small molecules, such as xenon.

Note: The unit cube is about $12 \AA$ on an edge. The hydrogen-bonded framework of water molecules consists of 46 water molecules per unit cube. Of these, there are two sets of 20 at the corners of pentagonal dodecahedra, one about the corner of the cube and one about the center of the cube. Six more water molecules aid in holding the dodecahedra together by hydrogen bonds. All hydrogen bonds, indicated by lines in the figure, are about $2.76 \AA$ long, as in ordinary ice. There is room in each dodecahedron for a small molecule; a symbol suggesting a molecule of $\mathrm{H}_{2} \mathrm{O}$ or $\mathrm{H}_{2} \mathrm{~S}$ is shown. Reprinted with permission from the American Association for the Advancement of Science. ${ }^{5}$ the higher concentrations possible by increasing ambient pressure, as does nitrogen. As no chemical reaction is involved, this suggests a physical basis as the mechanism of anesthesia. Pauling suggested that hydrates may "decrease the rate of chemical reactions by entrapping reactant molecules," but did not discuss oxygen, the most critical agent in the maintenance of consciousness, despite having invented the paramagnetic oxygen analyzer. Oxygen is poorly soluble in water and hydrates by causing perturbations of cell membranes ${ }^{6}$ may impede oxygen transport into neurons and reduce mitochondrial production of adenosine triphosphate.

Neurons are certainly sensitive to hypoxia: respiring a gas not containing oxygen causes immediate loss of consciousness. ${ }^{7}$ However, the concept of the "idling" neuron in which minimal levels of blood flow and, therefore, oxygen delivery can maintain cell viability without functional capability is now well-accepted. ${ }^{8}$ The many effects relevant to general anesthesia observed in studies of xenon may follow reductions in oxidative phosphorylation induced by hypoxia in the many regions of the nervous system. ${ }^{9}$ It remains to be seen if hypoxia-inducible factor 1 is detectable with other gaseous anesthetic agents.

The author is pleased to acknowledge helpful discussions with friend and colleague Duncan Black PhD FRCS.

\section{Philip B. James*}

Emeritus Professor of Medicine, University of Dundee, Scotland, UK

"Correspondence to: Philip B. James, MB, ChB, DIH, PhD, FFOM,

Professor Emeritus, pbjames1942@gmail.com. orcid: 0000-0002-4056-8130 (Philip B. James)

doi: $10.4103 / 2045-9912.304227$

How to cite this article: James PB. Evidence that gaseous anesthesia may be due to neuronal hypoxia. Med Gas Res 2020;10(4):201.

Copyright license agreement: The Copyright License Agreement has been signed by the author before publication.

Plagiarism check: Checked twice by iThenticate.

Peer review: Externally peer reviewed.

Open access statement: This is an open access journal, and articles are distributed under the terms of the Creative Commons AttributionNonCommercial-ShareAlike 4.0 License, which allows others to remix, tweak, and build upon the work non-commercially, as long as appropriate credit is given and the new creations are licensed under the identical terms.

\section{RefERENCES}

1. Glaisher J. Notes of effects experienced during recent balloon ascents. Lancet. 1862;80:559-560.

2. Meyer H. Zur theorie der alkoholnarkose. Arch Exp Pathol Pharmakol. 1901;46:338-346.

3. Overton E. Studien über die Narkose: zugleich ein Beitrag zur allgemeinen Pharmakologie. Jena, Switzerland: Gustav Fischer. 1901.

4. Stoppe C, Ney J, Brenke M, et al. Sub-anesthetic xenon increases erythropoietin levels in humans: a randomized controlled trial. Sports Med. 2016;46:1753-1766. Pauling L. A molecular theory of general anesthesia. Science. 1961;134:15-21.

6. Koubi L, Tarek M, Bandyopadhyay S, Klein ML, Scharf D. Membrane structural perturbations caused by anesthetics and nonimmobilizers: a molecular dynamics investigation. Biophys J. 2001;81:3339-3345.

7. James PB, Calder IM. Anoxic asphyxia--a cause of industrial fatalities: a review. $J R$ Soc Med. 1991;84:493-495.

8. Astrup J, Siesjö BK, Symon L. Thresholds in cerebral ischemia - the ischemic penumbra. Stroke. 1981;12:723-725.

9. Özugur S, Kunz L, Straka H. Relationship between oxygen consumption and neuronal activity in a defined neural circuit. BMC Biol. 2020;18:76.

Date of submission: August 26, 2020

Date of decision: August 26, 2020

Date of acceptance: August 26, 2020

Date of web publication: Dec 25, 2020 